\title{
Ethics briefings
}

Veronica English, Gillian Romano-Critchley, Ann Sommerville, Medical Ethics Department, British Medical Association

\section{Gene patenting}

The EC Directive on the Legal Protection of Biotechnological Inventions (98/44/EC), adopted by the European Parliament in July 1998, required all member states of the European Union to ensure that, by 30 July 2000, their national patent laws were consistent with the terms of the directive. This directive was the culmination of debate, consultation and fierce disagreement for more than a decade and, even in its final form, has remained controversial.

Although the directive states clearly that the human body is not patentable, it goes on to say that an element isolated from the human body or otherwise produced by a technical process "including the sequence or partial sequence of a gene" may constitute a patentable invention "even if the structure of that element is identical to that of a natural element". In order to be patentable, the application must also satisfy the criteria of novelty, of constituting an inventive step and of industrial applicability.

Shortly after the directive was passed the Dutch government appealed to the European Court of Justice following a vote by the parliament of the Netherlands against its adoption, on ethical grounds ${ }^{1}$. The Netherlands argued on technical grounds that the directive should have been subject to unanimous rather than majority voting. The written part of these proceedings is now closed and a hearing in front of the court of justice is likely to take place towards the end of the year.

The Norwegian Medical Association is leading the World Medical Association (WMA) in its opposition to the patenting of the human genome and presented a discussion paper to the WMA's Annual Council Meeting in April. In a press release following the meeting, the chairman of the WMA called on its national medical association members to approach their governments as a matter of urgency to prevent the patenting of the human genome because of "the potential limitation on the availability of new treatments for patients and on the restrictions this might place on the transfer of knowledge". ${ }^{2}$

One of the major concerns about the directive, based on the ambiguity of the wording, is uncertainty about the way in which it will be applied in practice. Lobbying for nonimplementation of the directive is unlikely to be productive, but lobbying for a code of practice to ensure appropriate and consistent application of the directive throughout Europe may be the way forward.

\section{Live births following abortion}

A coroner in the Northern Territory, Australia has called for uniform laws or protocols to be put in place to deal with situations in which babies are born alive following abortion. This follows the case of "Baby J" who was born alive following an induced delivery when the gestational age had been mistakenly assessed as 19 weeks. In fact, the gestational age was 22 weeks and the baby lived for 80 minutes after the termination attempt. ${ }^{3}$ Existing guidance from the UK's Royal College of Obstetricians and Gynaecologists states that "abortion must not result in the birth of a living child that then dies for reasons other than the severe abnormality for which the abortion was performed". It recommends that where abortion is induced at a gestation at which the fetus, after birth, might be capable of remaining alive by breathing through its lungs, it is "imperative" that the fetal heart is arrested before delivery. Whilst this guidance will address most situations, it does not cover situations, as in Baby J's case, where the gestational age is assessed incorrectly. A situation could also arise in which the woman, although consenting to the termination of pregnancy, does not consent to pro- cedures designed to stop the fetal heart before the abortion; it is unclear how health professionals would respond in such circumstances. Although general guidance from both the British Medical Associaton $(B M A)^{5}$ and the Royal College of Paediatrics and Child Health ${ }^{6}$ refers to the withholding and withdrawal of treatment from neonates, specific guidance may be needed.

\section{Euthanasia}

Euthanasia is the subject of perennial debate throughout Europe. The UK royal colleges of general practitioners and physicians concluded a joint project earlier this year and prepared a statement to go before their respective councils for publication in summer. In Germany, although euthanasia is illegal, a regional bioethics commission is to formulate euthanasia guidelines. ${ }^{7}$ France's national bioethics committee reported in January that voluntary euthanasia may be an option in some cases although the committee has not proposed a change in the law. ${ }^{8}$ Other countries are pursuing legislation. In the Netherlands a bill on voluntary euthanasia is progressing through parliament with the support of the government coalition. ${ }^{9}$ (During its passage, the bill was amended to remove proposals which would have allowed incurably ill children between the ages of 12 and 15 to request euthanasia with the agreement of their parents.) In Belgium a law to make it legal for a doctor to help a patient to die if explicitly and repeatedly requested is expected to be passed in summer. ${ }^{10}$ The law would also allow doctors to comply with a written advance request for euthanasia if the patient permanently loses consciousness.

Euthanasia in the Netherlands has always attracted enormous international debate. It is perhaps surprising that the situation in other European countries is less well known, although, for example, an altruistically 
motivated death by physician-assisted suicide in Switzerland is not punishable under Swiss law. The Swiss right to die organisation, EXIT, has its own guidelines outlining those they consider eligible for help from the organisation; these include that the person be 18 or over, a Swiss resident, mentally competent and suffering from intolerable health problems. ${ }^{1}$ EXIT has been helping patients since 1982, and around 100-120 people die with its assistance each year.

\section{Proxy decision making in Scotland}

The Scottish parliament's Adults with Incapacity (Scotland) Act received royal assent in May 2000. ${ }^{12}$ The act sets in statute doctors' authority to do "what is reasonable in the circumstances, in relation to medical treatment, to safeguard or promote the physical or mental health of ... [an incapacitated] adult" and introduces for the first time comprehensive powers for proxy health care decision making. Where a proxy has been appointed, doctors must seek his or her consent before treating. If there is disagreement, the view of a medical practitioner nominated by the Mental Welfare Commission must be sought. If the treating and nominated doctors agree that treatment should be given, treatment can go ahead even if the proxy refuses. If there is disagreement over treatment decisions, and agreement cannot be reached, any person with an "interest in the personal welfare of the adult" may apply to the court for determination as to whether the proposed treatment should be given. Proxies and nearest relatives also have the power to consent to ethics committee approved research.

\section{The Istanbul Protocol}

It is widely recognised that doctors are often the first in any society to see evidence of torture and police brutality through the provision of prison medical care, treatment in police stations and postmortem examinations. In addition, health workers in the immigration service or treating asylum seekers encounter torture survivors. Various protocols have been published to help identify sequelae of torture in survivors or cadaveric remains. In 1999, international cooperation between a wide range of health professionals, lawyers and human rights experts produced by far the most comprehensive guidance yet, "the Istanbul Protocol". The aim of the project was to provide clear and authoritative guidance for health and legal professionals about the documentation of evidence of torture. It was coordinated by the US organisation, Physicians for Human Rights, the Turkish Foundation for Human Rights and Turkish doctors. Experts from many other countries contributed to the evolution of the project through an e-mail working group lasting several years.

The protocol, which was finalised in Istanbul and strongly driven by the needs of Turkish health professionals to expose routine use of torture in Turkey, covers evidence-gathering and some issues of treatment. It tackles rarely discussed ethical dilemmas, such as the torture survivor's right to privacy, especially in relation to sexua torture, in the face of legal and moral duties to expose gross human rights violations. In August 1999, the document was formally submitted to the United Nations for approval. In April 2000, the UN Commission on Human Rights unanimously annexed to two of its resolutions the principles set out in the Istanbul Protocol. The resolutions are due to be considered by the UN General Assembly in autumn 2000. In the meantime, the Istanbul Protocol, (also known as the Manual on Effective Investigation and Documentation of Torture and Other Cruel, Inhuman or Degrading Treatment or Punishment) is being translated into Turkish with funding from the Organisation for Security and Cooperation in Europe. The document can be accessed by visiting www.phrusa.org; www.hrft.org.tr; and www.tivh.org.tr.

\section{Organ donation}

In June the British Medical Association (BMA) published a discussion paper, Organ Donation in the 21st Cen- tury. Time for a consolidated approach ${ }^{13}$ and, with the support of a number of other organisations, launched a campaign calling for a radical review of the organ donation system. The BMA's paper draws attention to the current shortage of organs available for donation and seeks action to reverse the increasing gap between the number of organs available and the number of patients needing a transplant. It considers ways of increasing the number of organs available for donation, including more direct appeals for people to register as potential donors, the increased use of living donors and non-heart-beating donors, and a change to a system of presumed consent with safeguards. It also suggests changes to the co-ordination of the service and the infrastructure to ensure that an increased number of organs leads to an increased number of transplants.

\section{References}

1 Dutch challenge to Brussels over biotech directive. Nature 1998;395:736.

2 World Medical Association press release. World Medical Association Council Meeting. 2000 May 8.

3 Loff B, Cordner S. Australian coroner recommends rules for abortions resulting in live births. Lancet 2000;355: ing in

4 Royal College of Obstetricians and Gynaecologists. Termination of pregnancy for fetal abnormality in England, Wales and Scotland. London: RCOG, 1996.

5 British Medical Association. Withholding and withdrawing life-prolonging medical treatment. Guidance for decision making. London: BMA, 1999.

6 Royal College of Paediatrics and Child Health. Withholding or withdrawing life saving treatment in children. A frameavork for practice. London: RCPCH, 1997.

7 German euthanasia guidelines. Lancet 2000;355:1440.

8 National Consultative Bioethics Committee for Health and Life Sciences. End of life, ending life, euthanasia. Paris: National Consultative Ethics Committee (CCNE), 2000.

9 HOLLAND: Health ministry drops plans for child euthanasia. Voluntary Euthanasia Society News. 1999 Oct 4.

10 BELGIUM: Plans for new euthanasia law. Voluntary Euthanasia Society News. 2000 Jan 5.

11 Voluntary Euthanasia Society. Assisted suicide in Switzerland. London: Voluntary Euthanasia Society, 1998.

12 Adults with Incapacity (Scotland) Act 2000.

13 British Medical Association. Organ donation in the 21st century. Time for a consolidated approach. London: BMA, 2000. 